\title{
Temporal variation in small nonvolant mammal (Cricetidae and Didelphidae) microhabitat associations in the Upper Paraná Atlantic Forest
}

\section{Variación temporal en asociaciones de microhábitats de pequeños mamíferos no voladores (Cricetidae y Didelphidae) en el Bosque Atlántico del Alto Paraná}

\author{
Robert D. Owen", II \\ 'Centro para el Desarrollo de Investigación Científica. Asunción, Paraguay \\ "Texas Tech University. Department of Biology. Lubbock, Texas, USA
}

\begin{abstract}
Many questions concerning habitat preferences of Neotropical small mammals remain unanswered. These questions include where the animal lives within and among the available habitats, and the temporal (seasonal and interannual) variation in the habitat associations. The objectives of this research were: (1) to determine the associations of non-volant small mammal species (Rodentia and Didelphimorphia) with specific microhabitat characteristics including vegetation structure in an area near the western boundary of the Upper Paraná Atlantic Forest, and (2) to evaluate seasonal and interannual variation in those associations. Three grids were sampled in three seasons (Dry, Wet, Variable) during two years (2015-2017). The four predominant small mammal species (Gracilinanus agilis, Akodon montensis, Hylaeamys megacephalus, and Oligoryzomys nigripes) were evaluated for seasonal and interannual variation in habitat preferences. Each of the four exhibited seasonal and/or interannual variation in microhabitat preferences for three to six of the 17 environmental variables analyzed. This is the first study to explicitly evaluate temporal variation in habitat associations of small mammals in the Atlantic Forest ecoregion. The temporal patterns of habitat association among these four predominant species reveal a complex spatially and temporally dynamic composition and structure in this small mammal community.
\end{abstract}

Keywords: El Niño. Environmental variables. Interannual variation. Paraguay. Seasonal variation. Vegetation structure.

Resumen: Muchas preguntas sobre las preferencias de hábitat de los pequeños mamíferos neotropicales siguen sin respuesta. Estas preguntas incluyen dónde vive el animal dentro y entre los hábitats disponibles, y la variación temporal (estacional e interanual) en las asociaciones de hábitats. Los objetivos de esta investigación fueron: (1) determinar las asociaciones de especies de mamíferos pequeños no voladores (Rodentia y Didelphimorphia) con características específicas de microhábitat, incluida la estructura de la vegetación en un área cerca del límite occidental del Bosque Atlántico del Alto Paraná, y (2) evaluar la variación estacional e interanual en estas asociaciones. Se tomaron muestras de tres parcelas en tres épocas (Seca, Húmeda, Variable) durante dos años (2015-2017). Cada uno de los cuatro pequeños mamíferos predominantes (Gracilinanus agilis, Akodon montensis, Hylaeamys megacephalus y Oligoryzomys nigripes) exhibió variación estacional y/o interanual en las preferencias de microhábitats para tres a seis de las 17 variables ambientales analizadas. Este es el primer estudio que evalúa explícitamente la variación temporal en las asociaciones de hábitat de pequeños mamíferos en la ecorregión del Bosque Atlántico. Los patrones temporales de asociación de hábitat entre estas cuatro especies predominantes revelan una estructura compleja espacial y temporalmente dinámica en esta comunidad de pequeños mamíferos.

Palabras claves: El Niño. Variables ambientales. Variación interanual. Paraguay. Variación estacional. Estructura de la vegetación.

OWEN, R. D., 2020. Temporal variation in small nonvolant mammal (Cricetidae and Didelphidae) microhabitat associations in the Upper Paraná Atlantic Forest. Boletim do Museu Paraense Emílio Goeldi. Ciências Naturais 15(3): 663-681. DOI: http://doi.org/10.46357/ benaturais.v15i3.260.

Autor para correspondência: Robert D. Owen. Raul Casal 2230 c/ Pizarro, Bo Republicano, C.P. 1371. Asunción, Paraguay (rowen@ pla.net.py).

Recebido em 18/01/2020

Aprovado em 04/12/2020

Responsabilidade editorial: Alexandra Maria Ramos Bezerra
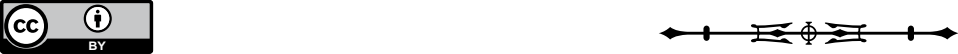


\section{INTRODUCTION}

In the Neotropics, sigmodontine rodents and didelphid marsupials often comprise rich components of the mammal communities (Emmons \& Feer, 1997; Solari et al., 2001; D'Elía \& Pardiñas, 2015; Owen et al., 2018). However, many questions concerning habitat preferences remain unanswered. These questions include where the animal lives within the habitat matrix, and the temporal (seasonal and interannual) variation in the habitat associations (Owen et al., 2019). Answers to these questions would enable better understanding of the composition and dynamics of marsupial and rodent communities on a local scale.

Over the past two decades, several studies have investigated habitat associations of small terrestrial mammals within the Southern Cone (primarily Brazil) of South America. Delciellos et al. (2016) concluded that habitat structure was an important determinant of mammal assemblages in fragments of Atlantic Forest in Rio de Janeiro state, Brazil. Distinct microhabitat associations were reported for a variety of species in southern Amazonia (Santos-Filho et al., 2008), secondary Atlantic Forest remnants (Püttker et al., 2008), a western Atlantic Forest region (Owen et al., 2010), a southern Atlantic Forest site (Melo et al., 2011, 2013), the Pampas region in southern Brazil (Sponchiado et al., 2012), and in the southwestern Cerrado (Smith et al., 2012; Carmignotto et al., 2014).

In this study, particular interest was focused on four small mammal species which are encountered abundantly in the Reserva Natural del Bosque Mbaracayú (RNBM), in the Upper Paraná Atlantic Forest (UPAF) of Paraguay, which is near the western limit of the Atlantic Forest (Eastwood et al., 2018; Barreto Cáceres \& Owen, 2019; Owen et al., 2020). Gracilinanus agilis (Burmeister, 1854) is a marsupial distributed in forests south of the Amazon Basin, east of the Andes and as far south as central Paraguay. The RNBM is near the southern limit of its distribution. Santos-Filho et al. (2008) reported that $G$. agilis was found both in forest and into a pasture matrix, and it is considered a generalist species. It is primarily arboreal (Smith et al., 2012) and utilizes dense understory vegetation of branches and vines (Carmignotto et al., 2015).

The rodent Akodon montensis Thomas, 1913 is distributed throughout the Atlantic Forest regions of Brazil, northeastern Argentina and eastern Paraguay, and into gallery forests of the Brazilian Cerrado (Pardiñas et al., 2016). The RNBM is near the western limit of its distribution at this latitude. Akodon montensis has been characterized as terrestrial (Cademartori et al., 2002; Vieira \& Monteiro-Filho, 2003; Naxara et al., 2009), although it also exhibits limited climbing behavior (Machado et al., 2019). It is not vulnerable to habitat fragmentation (Püttker et al., 2008; Jordão et al., 2010) and is tolerant of habitat degradation (Barreto Cáceres \& Owen, 2019).

Hylaeamys megacephalus (G. Fischer, 1814) is a tropical lowland forest oryzomyine, distributed from Trinidad and Tobago, the Caribbean and Atlantic coast of Venezuela and the Guianas, southward across eastern Amazonia and the Cerrado to central eastern Paraguay. The RNBM is near the southern limit of its distribution. Hylaeamys megacephalus is a generalist species with high habitat tolerance, inhabiting primary, secondary and degraded forests (Percequillo et al., 2016). In the Upper Paran Atlantic Forest it was encountered in all three levels of habitat degradation (Barreto Cáceres \& Owen, 2019; Owen et al., 2019). In the same forest, Owen et al. (2020) found them preferentially associated with bamboo understory.

Oligoryzomys nigripes (Olfers, 1818) is a small oryzomyine distributed from northeastern Brazil through the Atlantic Forest and Cerrado ecoregions southward through eastern Paraguay and northeastern Argentina to Uruguay (Bonvicino et al., 2016). The RNBM is near the western limit of its distribution at this latitude. $O$. nigripes is a habitat generalist (Martin et al., 2012; Garcia, 2018; Owen et al., 2020), generally found in forested areas (Cáceres et al., 2011), and not vulnerable to forest fragmentation (Püttker et al., 2008). Owen et al. (2019) found this species to consistently represent around $9 \%$ of the sigmodontine rodent community on sampling grids 
with three different levels of forest degradation, and it did not exhibit microhabitat selection.

This study was conducted in a heterogeneous landscape at the western limit of the Atlantic Forest, an extensive South American ecoregion. Previous studies hypothesized that in such marginal areas with a more heterogeneous forest habitat mosaic, small mammal species might be more strictly associated with the habitat(s) best fulfilling their niche requirements, and thus that microhabitat preference might be more detectable than in localities of more homogeneous habitat (Lozada \& Guthmann, 1998; Lozada et al., 2000; Bonvicino et al., 2002; Owen, 2013). Moreover, the close proximity of multiple microhabitats may facilitate the movement of resident small mammal species from one habitat type to another, so that they may alter their microhabitat associations through time, responding either to seasonal or irregular environmental variation between years. Finally, the four predominant species at the study site are all near their biogeographic limits, and thus may be restricted to certain habitat types within this marginal UPAF habitat. This study evaluates habitat preference explicitly on one scale, termed microhabitat, and evaluates seasonal and interannual variation in habitat associations for each of four common small-mammal species.

\section{MATERIALS AND METHODS}

\section{STUDY SITE}

The study was conducted in the Reserva Natural del Bosque Mbaracayú (RNBM), a natural reserve of 64,405.7 hectares that is located in Canindeyú department, northeastern Paraguay between latitudes -24.00 and -24.25 and longitudes -55.33 and -55.53 (Figure 1). This site is located within the climate type Cfa (temperate, without dry season, hot summer - Peel et al., 2007). The RNBM is located near the western margin of the Upper Paraná Atlantic Forest (UPAF), depicted as tropical and subtropical moist broadleaf forest in the biome map of Olson et al. (2001).
The reserve comprises a mosaic of ten different habitat types, eight of which are UPAF and two of which pertain to Cerrado (Naidoo \& Hill, 2006; Peña-Chocarro et al., 2010). This study was conducted within the mosaic of Atlantic Forest habitat types of the Reserve.

\section{SAMPLING DESIGN AND \\ ENVIRONMENTAL VARIABLES}

Three sampling grids were established, two of $12 \times 12$ stations and one of $13 \times 11$ : the centroid of Grid A (144 stations) was -24.1239, -55.5048; Grid B (143 stations) -24.1412, -55.3664; and Grid G (144 stations) -24.1306, -55.5369. Trap stations were separated by $10 \mathrm{~m}$. Each grid was sampled six times for five nights during three seasons (Dry, Wet and Variable, sensu Owen \& Camp, in press) for two years (June 2015 - March 2017). An extreme El Niño event occurred during the first of the two sampling years, with precipitation higher than average (DINAC, 2016), although maintaining the historical seasonal pattern of dry, wet and variable seasons (Figure 2).

During the first sampling session each station had one Sherman Trap ${ }^{\mathrm{TM}}(7.6 \times 8.9 \times 22.9 \mathrm{~cm})$ placed on the ground and one placed 1 to $2.5 \mathrm{~m}$ above ground in branches or vines. All subsequent sessions included two traps placed on the ground and one above ground. Total sampling effort for the study was 36,365 trapnights. A mixture of oats and peanut butter was used as bait in the traps, and they were rebaited each morning when checked for captures. For ease of comparing with previous studies based on this field investigation, grid designations (A, B, G) and sampling sessions (2 to 7) correspond with those in the these publications (e.g., Barreto Cáceres \& Owen, 2019; Owen et al., 2019; Sánchez-Martínez \& Owen, 2020). All animals captured in the third and sixth sampling session were collected and prepared as standard voucher specimens. A total of 1,143 vouchers were examined after preparation, and all field identifications were confirmed for the four species evaluated in this paper. 

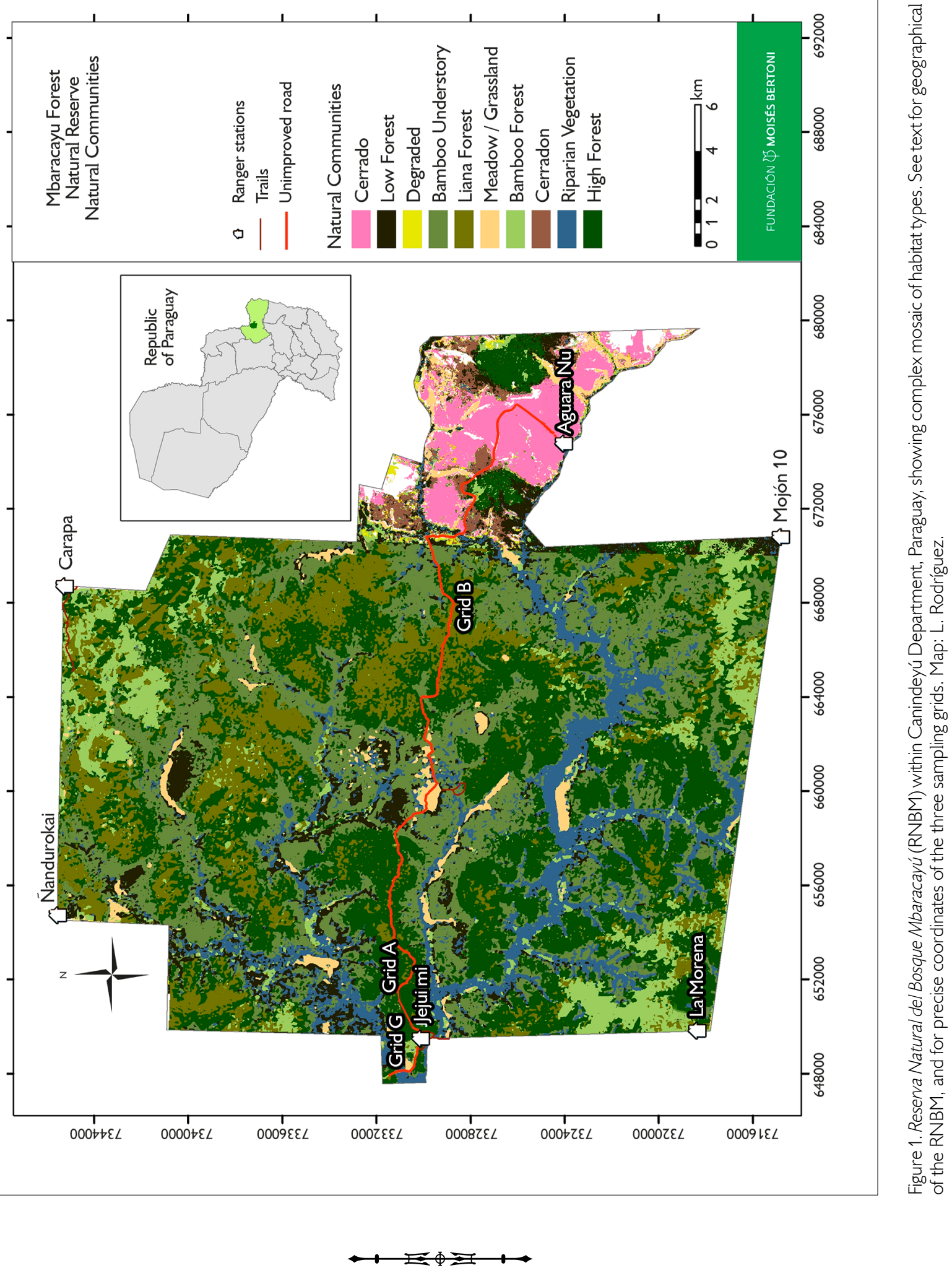
In this study microhabitat is defined as the habitat immediately surrounding each trap station within the habitat matrix of the forest. In practical terms it is measured as 17 environmental variables within an area of ca. $2 \mathrm{~m}$ in diameter centered on each trap station (Schnell et al., 2010; Poindexter et al., 2012). Measures were recorded at each of the 431 trap stations included in the three sampling grids, during the first mammal sampling session and repeated during the second session, to ensure that seasonal variation of environmental variables could be detected. No important differences ( $\geq 10 \%$ in $\geq 10$ of the cases) were found between the samples taken in different seasons. Thus, data from the two seasons were averaged for each station, and the mean values were used for the analyses reported here. Three of the 17 variables were nominal, one meristic, seven were percentages and six were direct-measure continuous variables (Table 1). Sampling methods for the environmental variables are described in Schnell et al. (2010) and Poindexter et al. (2012).
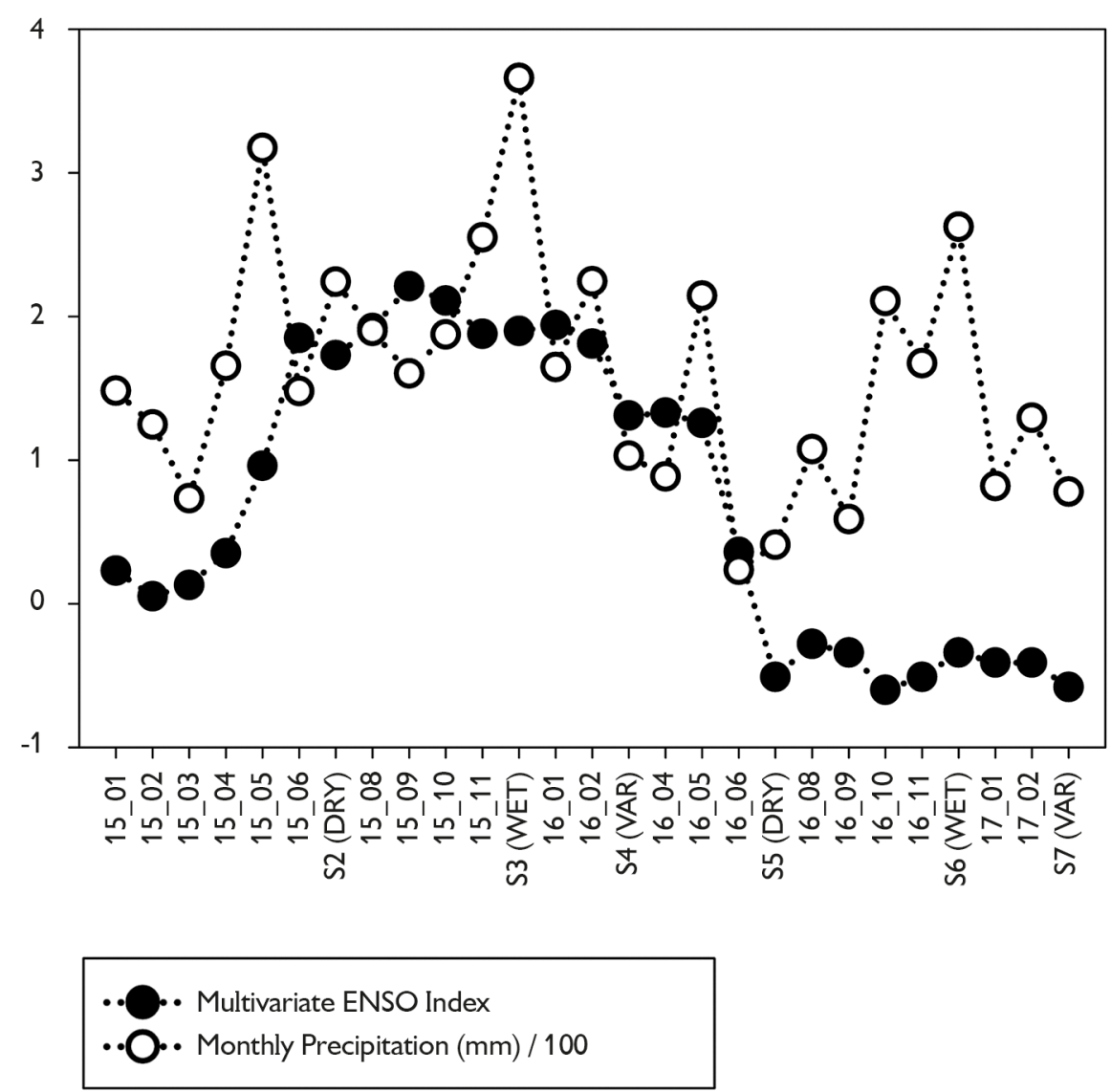

Figure 2. Multivariate ENSO Index (MEI) values and precipitation from January 2015 (approximately 6 months before first sample) through March 2017 (final sample). Abscissa is time (YR-MO), with sampling sessions 2-7 indicated in the month they occurred. MEI value shown for each month is the mean of that month and the previous month, i.e., 15 _01 is the mean of December 2014 and January 2015. Ordinate is MEI values (solid circles) and precipitation (open circles, in mm, divided by 100). Precipitation data from Climatic Research Unit (n. d.). MEI data from Multivariate ENSO Index (MEI) (n. d.).

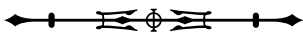


Table 1. List of classification variables used to identify each capture, and the 17 environmental variables measured to characterize the microhabitat. Sampling methods for the environmental variables as described in Schnell et al. (2010) and Poindexter et al. (2012).

\begin{tabular}{|c|c|}
\hline Variables & Description \\
\hline \multicolumn{2}{|l|}{ Classification } \\
\hline ID & Specific identification \\
\hline Year & $1=2015-16,2=2016-17$ \\
\hline Season & Dry (June-July), Wet (November-December), Variable (February-March) \\
\hline \multicolumn{2}{|c|}{ Environmental variables } \\
\hline \multicolumn{2}{|l|}{ Nominal } \\
\hline Orange & 1 or 0 , presence or absence of Citrus aurantium L., 1753 (invasive species) within $10 \mathrm{~m}$ \\
\hline $\log$ & 1 or 0 , presence or absence of log (fallen tree) within $10 \mathrm{~m}$ \\
\hline Height & 1 = captured on ground, 2 = captured above ground \\
\hline \multicolumn{2}{|l|}{ Meristic } \\
\hline Bushes & Number of bushes within $1 \mathrm{~m}$ \\
\hline \multicolumn{2}{|l|}{ Continuous } \\
\hline \multicolumn{2}{|l|}{ Direct } \\
\hline Slope & Slope of ground measured in degrees \\
\hline Treedist & Distance to nearest tree \\
\hline Canopy1 & Height of $1^{\text {st }}$ canopy \\
\hline Canopy2 & Height of $2^{\text {nd }}$ canopy \\
\hline Canopy3 & Height of $3^{\text {rd }}$ canopy \\
\hline Maxcan & Maximum canopy height \\
\hline \multicolumn{2}{|l|}{ Percentages } \\
\hline Percan & Percentage closure of canopy \\
\hline Woody & Percentage of $2 \times 2 \mathrm{~m}$ quadrat covered by woody plants \\
\hline Forbs & Percentage of $2 \times 2 \mathrm{~m}$ quadrat covered by forbs \\
\hline Grasses & Percentage of $2 \times 2 \mathrm{~m}$ quadrat covered by grasses \\
\hline Litter & Percentage of $2 \times 2 \mathrm{~m}$ quadrat covered by vegetative litter \\
\hline Deadwood & Percentage of $2 \times 2 \mathrm{~m}$ quadrat covered by dead wood \\
\hline Bare & Percentage of $2 \times 2$ m quadrat with no cover (bare ground) \\
\hline
\end{tabular}

\section{SMALL MAMMAL SAMPLING}

Field identification of animals and subsequent identification of prepared specimens followed keys provided in Voss \& Jansa (2009) and D'Elía \& Pardiñas (2015). Identifications of prepared specimens confirmed field identifications. All standard data of each captured individual were recorded: specific identification, weight, sex, reproductive status and age (adults, sub-adults or juveniles, based on external characteristics of reproductive status, juvenile or adult pelage and weight). Each animal was marked with a Passive Integrated Transponder (PIT) tag (Biomark, Inc.). Every capture was included in the analyses, as each capture was considered to be an independent expression of microhabitat preference by the species, as measured by the 17 environmental variables recorded for each station. Adults and subadults were included in the dataset but juveniles were not, as their capture location was presumed to be at least partially a function of their natal nest-site location (i.e., not selected by the juvenile individual). 
Animal sampling and collection were carried out under Scientific Collection Permits No. 011/2014, 132/2015 and 269/2016 (Secretary of the Environment, currently the Ministry of Environment and Sustainable Development, Paraguay), and the guidelines of the Animal Care and Use Committee of the American Society of Mammalogists (Sikes et al., 2011, 2016). Animal handling protocols were approved by the Institutional Animal Care and Use Committee of Texas Tech University (IACUC Approval No. 14024-03). Specimens ${ }^{1}$ are temporarily deposited in the author's research collection, which is an accredited research collection under Approval 004/2015 by the Secretary of the Environment, Paraguay. Following research use of the specimens, they will be deposited in an accredited Paraguayan collection. Tissue which were harvested from the specimens (including blood samples from the released specimens) are deposited in the Genetic Resources Collections of the Museum of Texas Tech University (TTU).

\section{ANALYTIC METHODS}

Using environmental variables from all sites with one or more captures, Spearman correlations were calculated among all pairs of environmental variables, in order to visualize overall correlation patterns of species-environmental associations. This provides a context within which to interpret correlations among variables for which one or more species have significant seasonal or interannual variation in preferences. These correlations analyses were conducted only on the environmental variables, disregarding the species which were captured at those trap stations.

Using all capture records during all sessions for the four species being evaluated, a series of Mann-Whitney Rank Sum pairwise comparisons was used to identify significant seasonal and interannual variation. Pairwise correlations were calculated between each of the species- variable associations showing significant temporal variation.

This was done separately for the suites of seasonal and interannual associations. For those species-variable pairs showing seasonal variation, Spearman Rank correlations were used to identify non-significant subsets among seasons. To visualize both the seasonal and interannual patterns of response of the four species to environmental variables, the data for each species were plotted for each variable for which the species showed significant temporal variation. A value of $P \leq 0.05$ was considered significant for all tests. All statistical tests were done using SigmaPlot ${ }^{\mathrm{TM}}$ 12.3 (Systat Software, Inc.).

\section{RESULTS}

A total of 1,614 captures (4.4\% trap success) were recorded during the study, including 947 individuals and 667 recaptures. The captures included two orders (Didelphimorphia and Rodentia), two families (Didelphidae and Cricetidae) and 17 species (Table 2 and complementary material). Of the 1,614 captures, 1,554 (96.3\%) were of subadult or adult animals and thus were included for the correlation analyses among environmental variables. Based on all environmental measures from all capture records, of the 136 pairwise comparisons among the 17 environmental variables, Spearman correlations were significantly positive for 38, negative for 53 , and non-significant for 45 (Figure 3). The number of positive correlations ranged from zero (Capture height) to seven (Canopy2); negative correlations from one (Capture height) to seven (Canopy2); and non-significant correlations from two (Slope, Litter) to 15 (Capture height). This indicates that in general (i.e., considering all species together), capture height of small mammals was independent of other environmental variables, whereas Canopy2 (height of second canopy) was either positively or negatively correlated with 14 of the 16 other environmental variables.

\footnotetext{
See complementary material to this article, in a table available at link: http://editora.museu-goeldi.br/bn/artigos/cnv15n3_2020/Owen_ tableS1.pdf
}

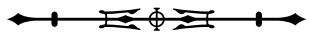



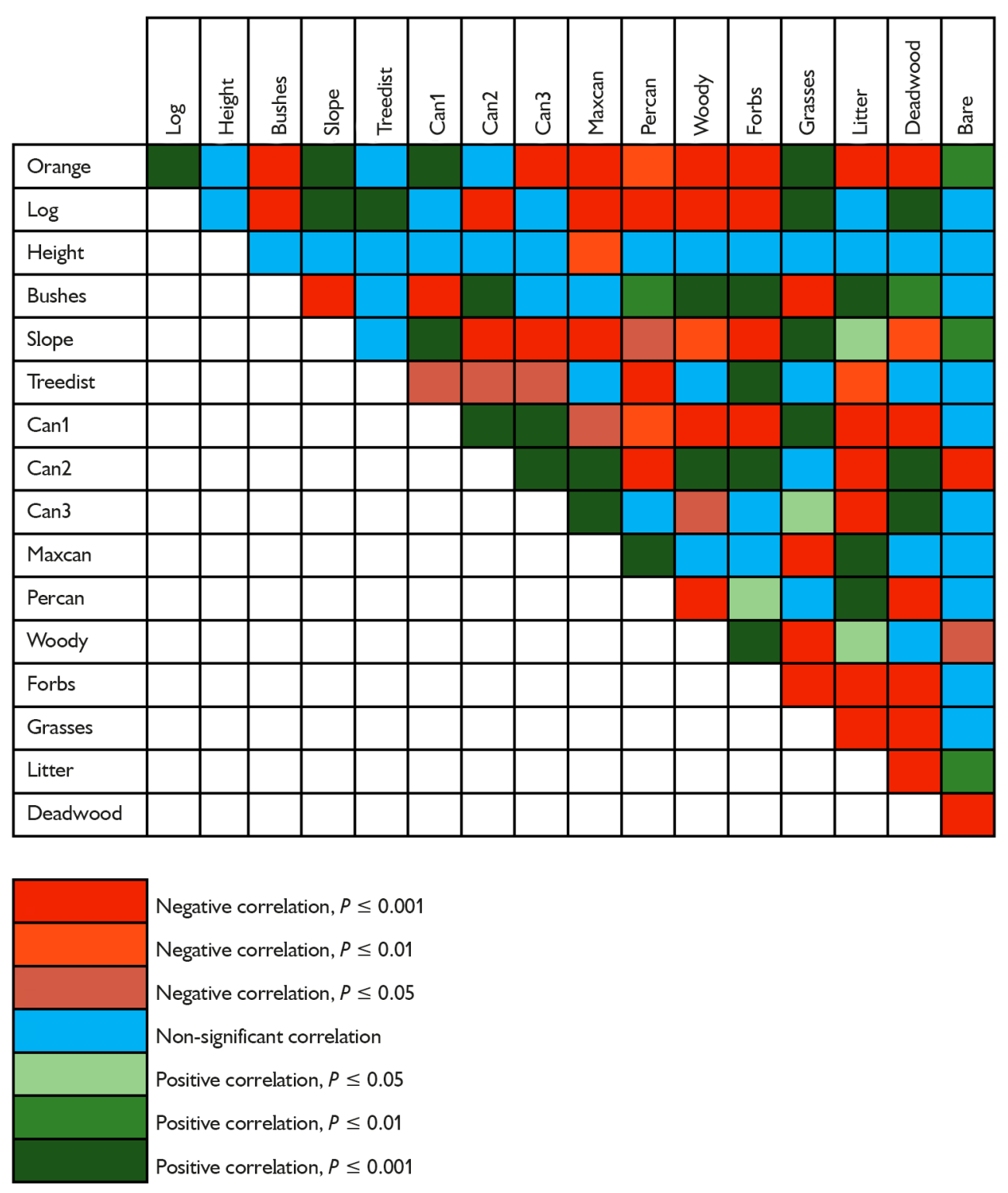

Figure 3. Heatmap indicating significance levels of Spearman correlations for all pairwise comparisons of environmental variables evaluated in this study, based on all 1,554 captures of 17 small mammal species.

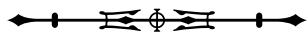


Only the species that were captured in all six sampling sessions (Gracilinanus agilis, Akodon montensis, Hylaeamys megacephalus, and Oligoryzomys nigripes) were included in the analyses of temporal variation in habitat preference (Table 2). Seasonal variation was found for six environmental variables, in one or two species, and seven variables were significant for interannual variation in one or two species (Table 3).

Gracilinanus agilis was more likely to be captured near Orange trees and Woody understory plants in the variable season, in an area with more Grasses in the wet season, and with more ground Litter in the dry season. Akodon montensis shared those seasonal preferences of Woody plants and Grasses, was captured near more ground Litter in the variable season, and with a higher Canopy 1 in the dry season. Hylaeamys megacephalus did not exhibit seasonal variation in its association with any environmental variable. Oligoryzomys nigripes was found associated with more Bare ground during the variable season (Table 4).

Table 2. Number of captures of adult and subadult individuals of small mammal species during the six sampling sessions evaluated in this study. Sampling sessions were: 2 = June - July 2015 (Dry season); 3 = November - December 2015 (Wet); 4 = February - March 2016 (Variable); 5 = June - July 2016 (Dry); 6 = November - December 2016 (Wet); 7 = February - March 2017 (Variable). Sampling session designations (2 to 7) correspond to designations used in other studies based on this field sampling (see Material and Methods).

\begin{tabular}{|c|c|c|c|c|c|c|c|}
\hline \multirow[b]{2}{*}{ Species } & \multicolumn{7}{|c|}{ Captures per sampling session } \\
\hline & 2 & 3 & 4 & 5 & 6 & 7 & Total \\
\hline \multicolumn{8}{|l|}{ Didelphimorphia } \\
\hline \multicolumn{8}{|l|}{ Didelphidae } \\
\hline Cryptonanus chacoensis (Tate, 1931) & 0 & 1 & 0 & 0 & 0 & 0 & 1 \\
\hline Gracilinanus agilis (Burmeister, 1854) & 16 & 2 & 2 & 12 & 5 & 9 & 46 \\
\hline Marmosa paraguayana (Tate, 1931) & 1 & 0 & 2 & 0 & 0 & 2 & 5 \\
\hline Monodelphis dimidiata (Wagner, 1847) & 0 & 0 & 0 & 0 & 2 & 0 & 2 \\
\hline Monodelphis kunsi Pine, 1975 & 0 & 0 & 0 & 0 & 0 & 1 & 1 \\
\hline \multicolumn{8}{|l|}{ Rodentia } \\
\hline \multicolumn{8}{|l|}{ Cricetidae } \\
\hline Akodon montensis Thomas, 1913 & 288 & 325 & 106 & 129 & 93 & 119 & 1060 \\
\hline Calomys callosus (Rengger, 1830) & 7 & 10 & 2 & 0 & 0 & 0 & 19 \\
\hline Euryoryzomys russatus (Wagner, 1848) & 0 & 1 & 0 & 0 & 0 & 0 & 1 \\
\hline Hylaeamys megacephalus (G. Fischer, 1814) & 60 & 26 & 50 & 34 & 15 & 22 & 207 \\
\hline Juliomys pictipes (Osgood, 1933) & 0 & 0 & 0 & 1 & 0 & 1 & 2 \\
\hline Necromys lasiurus (Lund, 1840) & 2 & 3 & 0 & 0 & 0 & 0 & 5 \\
\hline Oecomys mamorae (Thomas, 1906) & 0 & 0 & 0 & 0 & 1 & 0 & 1 \\
\hline Oligoryzomys mattogrossae (Allen, 1916) & 11 & 1 & 8 & 17 & 0 & 12 & 49 \\
\hline Oligoryzomys nigripes (Olfers, 1818) & 26 & 21 & 16 & 22 & 12 & 20 & 117 \\
\hline Oligoryzomys sp. & 1 & 0 & 10 & 9 & 2 & 2 & 24 \\
\hline Rhipidomys macrurus (Gervais, 1855) & 0 & 0 & 0 & 2 & 0 & 2 & 4 \\
\hline Sooretamys angouya (Fischer, 1814) & 0 & 1 & 1 & 1 & 5 & 2 & 10 \\
\hline Total & 412 & 391 & 197 & 227 & 135 & 192 & 1554 \\
\hline
\end{tabular}


Table 3. Environmental variables for the four abundant species that exhibited significant $(\alpha \leq 0.05$, by Mann-Whitney Rank Sum test) seasonal (Season) and/or interannual (Year) variation in their association (X). For description of variables see Table 1. Also included non significant (-) variables in the table for comparison with significant ones.

\begin{tabular}{lcccccccc}
\hline & \multicolumn{2}{c}{ Gracilinanus agilis } & \multicolumn{2}{c}{ Akodon montensis } & \multicolumn{2}{c}{ Hylaeamys megacephalus } & \multicolumn{2}{c}{ Oligoryzomys nigripes } \\
\multicolumn{1}{c}{ Variables } & Season & Year & Season & Year & Season & Year & Season & Year \\
\hline Orange & $\times$ & - & - & $\times$ & - & - & - & - \\
Log & - & - & - & - & - & $\times$ & - & - \\
Height & - & - & - & $\times$ & - & - & - & $\times$ \\
Bushes & - & - & - & - & - & - & - & - \\
Slope & - & - & - & - & - & $\times$ & - & - \\
Treedist & - & - & - & - & - & - & - & - \\
Canopy1 & - & - & $\times$ & - & - & - & - & - \\
Canopy2 & - & - & - & - & - & - & - & $\times$ \\
Canopy3 & - & - & - & - & - & - & - & - \\
Maxcan & - & - & - & - & - & - & - & - \\
Percan & - & - & - & - & - & - & - & - \\
Woody & $\times$ & - & $\times$ & - & - & - & - & - \\
Forbs & - & - & - & - & - & - & - & - \\
Grasses & $\times$ & - & $\times$ & $\times$ & - & $\times$ & - & - \\
Litter & $\times$ & - & $\times$ & $\times$ & - & - & - & - \\
Deadwood & - & - & - & - & - & - & - & - \\
Bare & - & - & - & - & - & - & $\times$ & - \\
\hline
\end{tabular}

Table 4. Subsets of non-significantly different seasonal means (indicated by shared letters A or B, $\alpha \leq 0.05$, by Spearman rank correlations) of the variables for which small nonvolant mammal species showed seasonal variation. For descriptions of environmental variables see Table 1. Seasons: $\mathrm{W}=$ wet, $\mathrm{D}=$ Dry, $\mathrm{V}=$ Variable.

\begin{tabular}{|c|c|c|c|c|c|c|c|c|c|c|c|}
\hline \multicolumn{4}{|c|}{ Gracilinanus agilis } & \multicolumn{4}{|c|}{ Akodon montensis } & \multicolumn{4}{|c|}{ Oligoryzomys nigripes } \\
\hline \multicolumn{4}{|c|}{ Orange } & \multicolumn{4}{|c|}{ Canopy1 } & \multicolumn{4}{|c|}{ Bare } \\
\hline Season & Mean & & & Season & Mean & & & Season & Mean & & \\
\hline W & 0.00 & A & B & V & 1.22 & A & & $\mathrm{D}$ & 0.10 & A & \\
\hline D & 0.04 & A & & W & 1.28 & & B & W & 0.23 & A & B \\
\hline$\vee$ & 0.27 & A & B & $\mathrm{D}$ & 1.29 & & B & V & 0.76 & & $\mathrm{~B}$ \\
\hline \multicolumn{4}{|c|}{ Woody } & \multicolumn{4}{|c|}{ Woody } & & & & \\
\hline Season & Mean & & & Season & Mean & & & & & & \\
\hline W & 5.71 & A & & W & 7.49 & A & & & & & \\
\hline D & 7.79 & A & & $\mathrm{D}$ & 8.30 & A & B & & & & \\
\hline $\mathrm{V}$ & 14.32 & & B & V & 8.48 & & B & & & & \\
\hline
\end{tabular}


Table 4

\begin{tabular}{|c|c|c|c|c|c|c|c|c|}
\hline \multicolumn{4}{|c|}{ Gracilinanus agilis } & \multicolumn{4}{|c|}{ Akodon montensis } & Oligoryzomys nigripes \\
\hline \multicolumn{4}{|c|}{ Grasses } & \multicolumn{4}{|c|}{ Grasses } & \\
\hline Season & Mean & & & Season & Mean & & & \\
\hline V & 2.27 & A & & V & 11.69 & A & & \\
\hline$D$ & 7.79 & A & & $\mathrm{D}$ & 14.72 & A & & \\
\hline W & 25.00 & & B & W & 16.45 & & B & \\
\hline \multicolumn{4}{|c|}{ Litter } & \multicolumn{4}{|c|}{ Litter } & \\
\hline Season & Mean & & & Season & Mean & & & \\
\hline W & 37.86 & A & & $\mathrm{D}$ & 45.16 & $A$ & & \\
\hline V & 55.68 & & B & W & 46.00 & $A$ & & \\
\hline$D$ & 56.54 & & B & $\vee$ & 49.18 & & B & \\
\hline
\end{tabular}

\section{CORRELATIONS AMONG SPECIES-VARIABLE ASSOCIATIONS}

Among significant seasonal species-variable associations, those of $G$. agilis to Orange trees and $A$. montensis to Litter were positively correlated (i.e. a concordant temporal pattern was observed in the data), as were those of $A$. montensis to both Canopy1 and Grasses. The temporal pattern of $G$. agilis with regard to Woody plants was negatively correlated with the same species' seasonal association with Grasses, as were those of $G$. agilis to Woody plants and $A$. montensis to Canopy1. Of 36 possible pair-wise correlations among species-variable associations, 32 were non-significant (Figure 4A).

Among the 36 possible correlations of significant interannual species-variable associations, five were found to be positively correlated and three negatively correlated (Figure 4B). The interannual pattern exhibited by $A$. montensis with regard to Orange trees and Height of capture was concordant with the response of the same species to Grasses and Litter, respectively. The response of A. montensis to Orange trees and Grasses was concordant in both cases with those of $H$. megacephalus to Grasses, and the response of $O$. nigripes to Canopy2. The response of $O$. nigripes to capture Height was negatively correlated to the response to Grasses by both $A$. montensis and $H$. megacephalus, and the response of $O$. nigripes to Canopy2 was negatively correlated to the same species' response to Height. Twenty-eight of the 36 possible correlations were non-significant.

Significant seasonal and interannual responses of the four species to environmental variables are graphed in Figure 5. These graphs show the temporal association of the species with the variables, and indicate whether the significantly correlated response is seasonal, interannual or both.

\section{SEASONAL VARIATION}

Six of the 17 environmental variables (Orange tree, Canopy1, Woody plants, Grasses, Litter, Bare ground) had seasonally variable responses from one or two of the four species examined. Three of the four abundant species exhibited seasonal variation in their associations with from one to four environmental variables. Both $G$. agilis and $A$. montensis exhibited temporal variation in associations with four variables, three of which (Woody plants, Grasses and Litter) were the same. Oligoryzomys nigripes showed seasonal variation in its association with Bare ground, being most strongly associated with this variable in the Variable season. Hylaeamys megacephalus was not found to have seasonal variation in association with any environmental variable. 


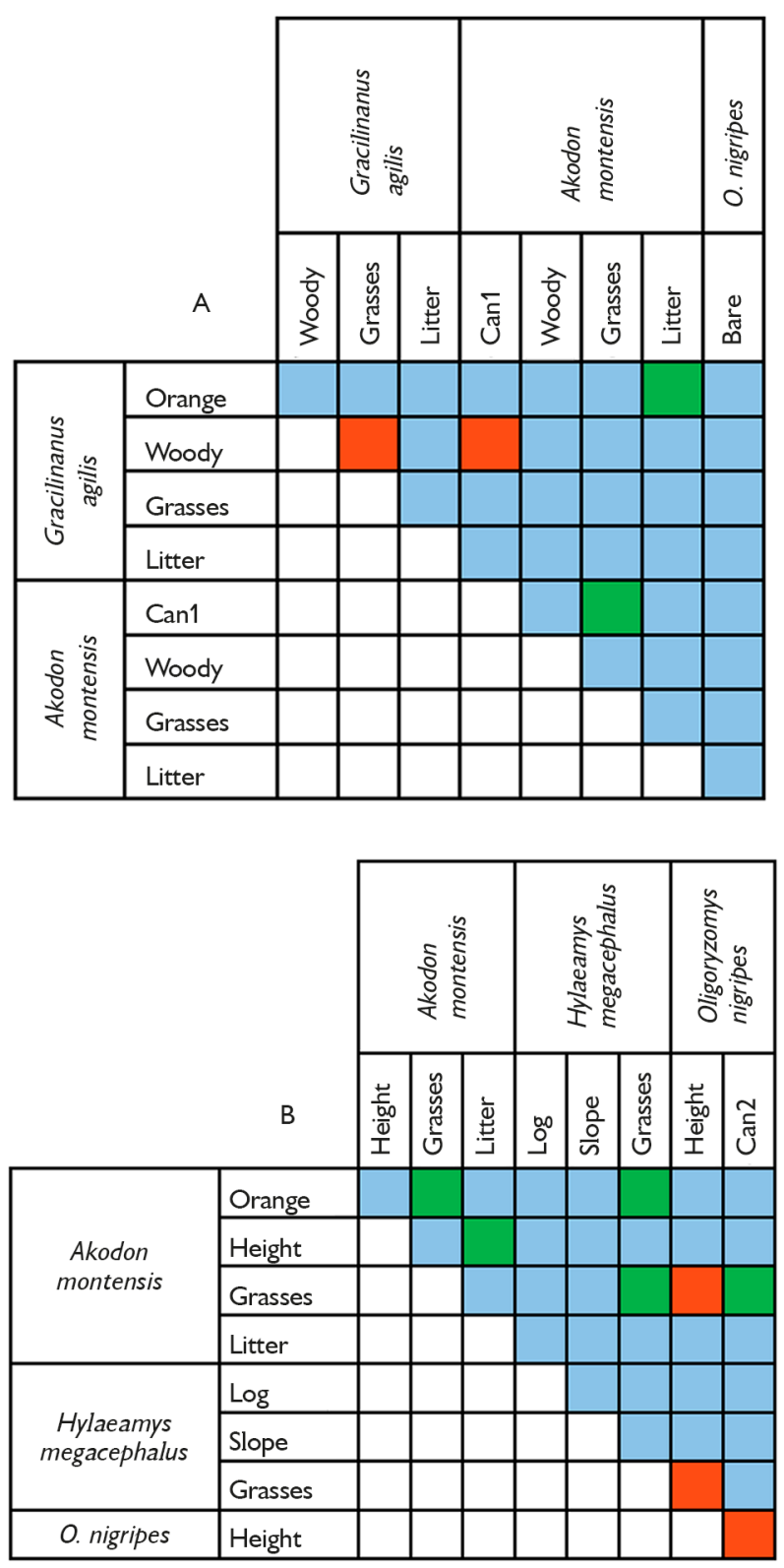

Negative correlation, $P \leq 0.05$

Non-significant correlation

Positive correlation, $P \leq 0.05$

Figure 4. Heatmaps indicating significance levels of Spearman correlations for all pairwise comparisons of environmental variables for which a small mammals species exhibited significant seasonal (A) or interannual (B) variation in association with the variable.

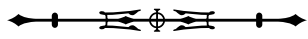




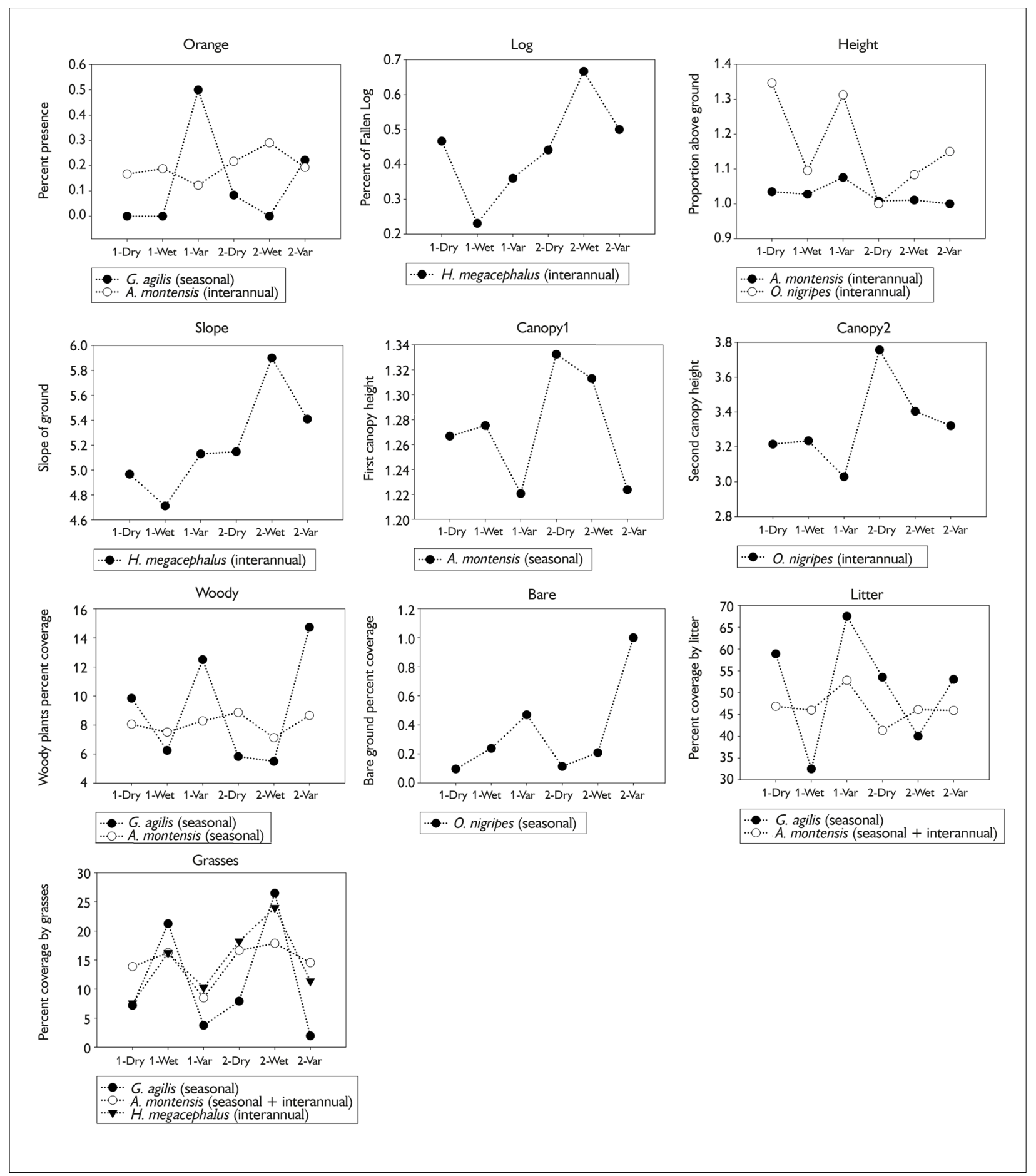

Figure 5. Environmental variables for which one or more species exhibited significant seasonal or interannual variation. Six samples were conducted, with samples in the Dry, Wet and Variable seasons of each of two years. Abscissa indicates sampling year (1 or 2) and season (Dry, Wet, Variable). Legend below each graph indicates the species exhibiting significant variation, and whether the variation was seasonal, interannual or both. 


\section{INTERANNUAL VARIATION}

Seven of the 17 environmental variables showed interannual variation in microhabitat preference by one or more of the four abundant species. The marsupial Gracilinanus agilis did not exhibit interannual variation in association with any environmental variable, whereas the three rodent species showed significant interannual differences in their associations with from two to four environmental variables. Akodon montensis associated more strongly in the first (El Niño) year with Litter and was captured more frequently above the ground, and in the following (normal) year associated more strongly with Orange trees and Grasses. Hylaeamys megacephalus associated more strongly in the normal year with fallen Logs, steeper Slope and more Grasses. Oligoryzomys nigripes exhibited higher average capture Height in the El Niño year, and was associated with a higher Canopy2 in the normal year.

\section{DISCUSSION}

\section{MICROHABITAT PREFERENCES OF PREDOMINANT SPECIES}

\section{Gracilinanus agilis}

This small opossum is highly arboreal (Smith et al., 2012), and 45 of 46 (97.8\%) of captures in this study were above the ground. In the forested areas of the Cerrado and the Atlantic Forest, it is found in Cerradão and gallery forest (Alho, 2005), in semi-deciduous transitional forest (Smith et al., 2012) and in forests with dense understory vegetation (Carmignotto et al., 2015). Barreto Cáceres \& Owen (2019) reported higher population levels in areas of greater forest degradation in an Interior Atlantic Forest site, although it was present in all degradation levels sampled. Although Alho (2005) reported seasonal populational variation, no previous study has examined temporal variation in microhabitat preference by this species. In the present study $G$. agilis did not exhibit interannual variation in microhabitat preference, but did show seasonal variation with respect to four environmental variables. Three of these four variables (Woody plants, Litter, Grasses) pertain to ground cover. These results suggest that this didelphid species is more responsive to ground-level habitat variables than previously understood, and conversely may be less influenced by other structural variables (e.g., distance to nearest tree and canopy heights) than would be expected for a primarily arboreal species.

\section{Akodon montensis}

This species is primarily terrestrial (1,031 of 1,060 [97.3\%] of captures were on the ground). Naxara et al. (2009) found $A$. montensis in approximately equal abundance and site occupancy in the cool-dry and the warm-wet seasons in an old-growth forest in São Paulo State. Although they did not explicitly evaluate temporal variation in habitat preference, Owen et al. (2010) noted that population densities of $A$. montensis exhibited different temporal patterns in three different habitats, suggesting that the different habitats were differentially favorable to this species through seasonal and/or annual cycles. A 23-month mark-recapture study of small mammals in a Cerrado locality in eastern Paraguay found that $A$. montensis was encountered during sampling sessions from May - September (dry season), and not at other times (Owen, 2013). In the present study, A. montensis showed significant seasonal variation for two environmental variables, interannual variation with two variables, and both seasonal and interannual variation with two other variables. Of these, three are ground-cover variables (Woody plants - seasonal, Litter-seasonal and interannual, Grasses - seasonal and interannual), which concurs with reports of the importance to $A$. montensis of dense understory vegetation, bamboo abundance, ferns and shrubs (Dalmagro \& Vieira, 2005; Goodin et al., 2009; de Lima et al., 2010; Melo et al., 2011, 2013). This species showed weaker preference for Grasses and stronger preference for Litter during the El Niño year. It also was captured above ground more often in the El Niño year. 


\section{Hylaeamys megacephalus}

This species exhibits population fluctuations associated with seasonal cycles. In the central Cerrado, it was captured most frequently in the wet season (Carmignotto et al., 2014), but in the western Interior Atlantic Forest it was more abundant in the dry season (Barreto Cáceres \& Owen, 2019). However no previous study has been made of temporal variation in habitat preference of $H$. megacephalus. This study found no seasonal variation in habitat associations of this species. Nevertheless, interannual differences were exhibited for three environmental variables (fallen Logs, ground Slope and Grasses). In the El Niño year, it had low preference for fallen Logs in the wet season, whereas in the wet season of the following year it showed high preference for Logs. The same pattern was found for ground Slope, perhaps having to do with the rate of rainfall runoff. Hylaeamys megacephalus showed a higher preference for Grasses in the wet season in both years, but the preference was weaker during the El Niño year.

\section{Oligoryzomys nigripes}

Although considered scansorial (using both the ground and bushes or vines), 97 of 117 (82.9\%) of captures of Oligoryzomys nigripes in this study were on the ground. This species is considered tolerant of a wide range of habitats, having been reported as occupying both flooded and unflooded grassland and forest in the Brazilian pampas (Sponchiado et al., 2012), and not preferentially associated with any of the vegetation variables in a study in Argentina (Gómez-Villafañe et al., 2012). Other reports have found an association with fallen logs, ground litter, vegetation density at $1 \mathrm{~m}$ and a high density of scrubs (Dalmagro \& Vieira, 2005; de Lima et al., 2010; Barreto Cáceres \& Owen, 2019). Temporal population variation has been reported for this species. Barreto Cáceres \& Owen (2019) found higher population levels in an El Niño year than in the following year. Few previous studies are available of temporal variation in habitat preference by Oligoryzomys nigripes. Bonvicino et al. (2016) state that it prefers more open areas in the dry season, but this statement is unreferenced. In an isolated Cerrado patch in an Atlantic Forest matrix, Owen (2013) reported O. nigripes was encountered in small numbers during May, August and September, but not in other months. In the present study the species was found to exhibit both seasonal and interannual responses to some environmental variables. In the El Niño year, it was captured above the ground more often, but in areas with a lower second canopy. It was found in areas of bare ground least often in the dry season, in contrast to the description by Bonvicino et al. (2016).

\section{INTERANNUAL VARIATION IN COMMUNITY STRUCTURE}

This study found 16 significant seasonal and/or interannual associations between four species and ten environmental variables, strongly indicating that small-mammal community structure and composition are temporally dynamic, and that the species respond in complex and specifically distinct ways to a variety of environmental variables. Three of the four predominant species exhibited an interannual response to two or more environmental variables. Although the study did not include replicates of the interannual variation, it is likely that the El Niño event, with concordant increased precipitation (Figure 2), was an important driver of interannual variation. As noted, the didelphid Gracilinanus agilis did not exhibit an interannual response to any environmental variable, whereas each of the sigmodontine rodents did. This is strong evidence that an El Niño event could affect small mammal community structure in important ways, via the changing microhabitat associations of the more abundant species in this marginal Atlantic Forest region. As noted, this study was conducted near the distributional limits of each of the four predominant small mammal species encountered in the study. Further research should focus on whether the potential 'El Niño' effect is characteristic of these species throughout their distributions, or only near their distributional limits. 


\section{CONCLUSIONS}

This is the first study to explicitly evaluate temporal variation in habitat associations of small mammals in the Atlantic Forest ecoregion. Each of four species exhibited seasonal and/or interannual variation in several of the habitat variables analyzed. Some of these species-variable associations were found to be concordant (correlated positively) or opposed (correlated negatively). Interannual variation might be attributable to the extreme El Niño event during the first year of the study, with Akodon montensis, Hylaeamys megacephalus, and Oligoryzomys nigripes showing significant interannual differences in their associations with four, three and two environmental variables respectively, while Gracilinanus agilis showed no interannual variation for any variable. Considered together, the differing temporal patterns of habitat association among these four predominant small mammals reveal a complex spatially and temporally dynamic composition and structure in this Atlantic Forest community. Further explicitly experimental studies would be required to discern specific physiologic or behavioral characteristics of the four species that result in the patterns observed in this study.

\section{ACKNOWLEDGEMENTS}

I thank A. M. R. Bezerra for inviting me to contribute to this special issue of the Boletim. At the Fundación Moises Bertoni, M. Velásquez, D. Salas, L. Rodriguez, S. Fernández, F. Ramírez and A. Alfonzo are thanked for innumerable acts of assistance-administrative, logistical and otherwise. At the Secretaría del Ambiente (now the Ministerio del Ambiente y Desarrollo Sustentable), I thank C. Morales, R. Duré, M. Motte, F. Bauer, B. Garcete, R. Barreto and N. Neris for approval of the various permits required for this project. Vegetation data were carefully collected and recorded by A. Rivarola, M. Sánchez, D. Bueno, P. Bogado and E. Galeano. Numerous people helped with establishing the sampling grids and during the six mammal sampling sessions, including V. Martínez, B. Barreto, J. Sánchez, E. Galeano, C. Solà Riera, E. Williams, G. Eastwood, H. Sánchez, E. Ríos,
C. Jonsson, L. Valdivieso and A. Pérez-Umphrey. E. Rios, J.

Sánchez and B. Barreto prepared the voucher specimens. L. Rodríguez prepared the map for Figure 1. J. Camp, five anonymous reviewers and A. Bezerra provided thoughtful comments on earlier versions of the manuscript. L. Aquino reviewed and corrected the Resumen. Financial support was provided by National Institutes of Health $(\mathrm{NIH})$ Grant I103053 to C.B. Jonsson and the author, through the $\mathrm{NIH}$ NSF Ecology of Infectious Disease Program. The author was partially supported by the Programa Nacional de Incentivo a los Investigadores (CONACYT, Paraguay).

\section{REFERENCES}

ALHO, C. J. R., 2005. Intergradation of habitats of non-volant small mammals in the patchy Cerrado landscape. Arquivos do Museu Nacional 63(1): 41-48.

BARRETO CÁCERES, M. B. \& R. D. OWEN, 2019. Relación de los pequeños mamíferos terrestres (Rodentia y Didelphimorphia) con la estructura de la vegetación en el Bosque Atlántico Interior un análisis multivariado. Therya 10(3): 359-369. DOI: https://doi. org/10.12933/therya-19-819

BONVICINO, C. R., S. M. LINDBERGH \& L. S. MAROJA, 2002. Small non-flying mammals from conserved and altered areas of Atlantic Forest and Cerrado: comments on their potential use for monitoring environment. Brazilian Journal of Biology 62(4b): 765774. DOI: https://doi.org/10.1590/S1519-69842002000500005

BONVICINO, C., G. D'ELÍA \& P. TETA, 2016. Oligoryzomys nigripes. The IUCN Red List of Threatened Species 2016: e.T15253A22358209. DOI: https://dx.doi.org/10.2305/IUCN. UK.2016-2.RLTS.T15253A22358209.en

CÁCERES, N. C., M. N. GODOI, W. HANNIBAL \& V. L. FERREIRA, 2011. Effects of altitude and vegetation on small-mammal distribution in the Urucum Mountains, western Brazil. Journal of Tropical Ecology 27(3): 279-287. DOI: https://doi.org/10.1017/ S0266467410000854

CADEMARTORI, C. V., R. V. MARQUES, S. M. PACHECO, L. R. M. BAPTISTA \& M. GARCIA, 2002. Roedores ocorrentes em floresta ombrófila mista (São Francisco de Paula, Rio grande do Sul) e a caracterização de seu hábitat. Comunicações do Museu de Ciências e Tecnologia PUCRS 15: 61-86.

CARMIGNOTTO, A. P., A. M. R. BEZERRA \& F. H. G. RODRIGUES, 2014. Nonvolant small mammals from a southwestern area of Brazilian Cerrado: diversity, habitat use, seasonality, and biogeography. Therya 5(2): 535-558. DOI: https://doi.org/10.12933/ therya-14-197 
CARMIGNOTTO, A. P., S. SOLARI, N. DE LA SANCHA \& L. COSTA, 2015. Gracilinanus agilis. The IUCN Red List of Threatened Species 2015: e.T9417A22169828. DOI: https://dx.doi.org/10.2305/ IUCN.UK.2015-4.RLTS.T9417A22169828.en

CLIMATIC RESEARCH UNIT, [n. d.]. CRU TS Version 4.02 Google Earth Interface. Available at: https://crudata.uea.ac.uk/cru/data/hrg/ cru_ts_4.02/ge/. Accessed on: 17 March 2019.

DALMAGRO, A. D. \& E. M. VIEIRA, 2005. Patterns of habitat utilization of small rodents in an area of Araucaria forest in Southern Brazil. Animal Ecology 30(4): 353-362. DOI: https://doi.org/10.1111/ j.1442-9993.2005.01447.x

DELCIELLOS, A. C., M. V. VIEIRA, C. E. V. GRELLE, P. COBRA \& R. CERQUEIRA, 2016. Habitat quality versus spatial variables as determinants of small mammal assemblages in Atlantic Forest fragments. Journal of Mammalogy 97(1): 253-265. DOI: https:// doi.org/10.1093/jmammal/gyv175

D'ELÍA, G. \& U. F. J. PARDIÑAS, 2015. Subfamily Sigmodontinae Wagner, 1843. In: J. L. PATTON, U. F. J. PARDIÑAS \& G. D'ELÍA (Ed.): Mammals of South America: vol. 2 Rodents: 63-688. The University of Chicago Press, Chicago.

DE LIMA, D. O., B. O. AZAMBUJA, V. L. CAMILOTTI \& N. C. CÁCERES, 2010. Small mammal community structure and microhabitat use in the austral boundary of the Atlantic Forest, Brazil. Zoologia 27(1): 99-105. DOI: http://dx.doi.org/10.1590/ S1984-46702010000100015

DIRECCIÓN NACIONAL DE AERONÁUTICA CIVIL (DINAC), 2016. El episodio de El Niño 2015/16 excepcionalmente intenso. Efectos en Paraguay. Dirección de Meteorología e Hidrología, Asunción, Paraguay.

EASTWOOD, G., J. V. CAMP, Y. K. CHU, A. M. SAWYER, R. D. OWEN, X. CAO, M. K. TAYLOR, L. VALDIVIESO-TORRES, R. D. SAGE, A. YU, D. G. GOODIN, V. J. M. BRUYN, R. C. MCALLISTER, L. RODRIGUEZ, E. P. WILLIAM \& C. B. JONSSON, 2018. Habitat, species richness and hantaviruses of sigmodontine rodents within the Interior Atlantic Forest, Paraguay. PloS ONE 13(8): e0201307. DOI: https://doi.org/10.1371/journal.pone.0201307

EMMONS, L. H. \& F. FEER, 1997. Neotropical rainforest mammals. A field guide. University of Chicago Press, Chicago.

GARCIA, G. V., 2018. Efecto de las plantaciones de pino sobre la diversidad y composición de un ensamble de micromamíferos no voladores del Bosque Atlántico del Alto Paraná en el norte de la provincia de Misiones, Argentina. Ph.D. Thesis - Universidad de Buenos Aires, Argentina.

GÓMEZ-VILLAFAÑE, I. E., Y. EXPÓSITO, Á. SAN MARTÍN, P. PICCA \& M. BUSCH, 2012. Rodent diversity and habitat use in a protected area of Buenos Aires province, Argentina. Revista Mexicana de Biodiversidad 83(3): 762-771. DOI: https://doi. org/10.7550/rmb.25126
GOODIN, D. G., R. PAIGE, R. D. OWEN, K. GHIMIRE, D. E. KOCH, Y.-K. CHU \& C. B. JONSSON, 2009. Microhabitat characteristics of Akodon montensis, a reservoir for hantavirus, and hantaviral seroprevalence in an Atlantic forest site in eastern Paraguay. Journal of Vector Ecology 34(1): 104-113. DOI: https:// doi.org/10.1111/j.1948-7134.2009.00013.x

JORDÃO, J. C., F. N. RAMOS \& V. X. DE SILVA, 2010. Demographic parameters of Akodon montensis (Mammalia: Rodentia) in an Atlantic Forest remnant of Southeastern Brazil. Mammalia 74(4): 395-400. DOI: https://doi.org/10.1515/MAMM.2010.045

LOZADA, M. \& N. GUTHMANN, 1998. Microhabitat selection under experimental conditions of three sigmodontine rodents. EcoScience 5(1): 51-55. DOI: https://doi.org/10.1080/11956860.1998.11682450

LOZADA, M., N. GUTHMANN \& N. BACCALA, 2000. Microhabitat selection of five sigmodontine rodents in a forest-steppe transition zone in northwestern Patagonia. Studies on Neotropical Fauna \& Environment 35(2): 85-90. DOI: https://doi.org/10.1076/01650521(200008)35:2;1-9;FT085

MACHADO, A. F., C. F. MARKS, B. PERES, G. L. MELO \& N. C. CÁCERES, 2019. Movement and use of environmental structures, climbing supports and shelters by Akodon montensis (Sigmodontinae, Rodentia) in the Atlantic Forest of southern Brazil. Mammalia 84(1): 107-113. DOI: https://doi.org/10.1515/mammalia-2018-0096

MARTIN, P. S., C. GHELER-COSTA, P. C. LOPES, L. M. ROSALINO \& L. M. VERDADE, 2012. Terrestrial non-volant small mammals in agro-silvicultural landscapes of Southeastern Brazil. Forest Ecology and Management 282: 185-195. DOI: http://dx.doi.org/10.1016/j. foreco.2012.07.002

MELO, G. L., J. SPONCHIADO, A. F. MACHADO \& N. C. CÁCERES, 2011. Small-mammal community structure in a South American deciduous Atlantic Forest. Community Ecology 12(1): 58-66. DOI: https://doi.org/10.1556/ComEc.12.2011.1.8

MELO, G. L., B. MIOTTO, B. PERES \& N. C. CÁCERES, 2013. Microhabitat of small mammals at ground and understorey levels in a deciduous, southern Atlantic Forest. Anais da Academia Brasileira de Ciências 85(2): 727-736. DOI: http://dx.doi.org/10.1590/S000137652013000200017

MULTIVARIATE ENSO INDEX (MEI), [n. d.]. Multivariate ENSO Index Version 2 (MEI.v2). Available at: https://www.esrl.noaa.gov/ psd/enso/mei/data/meiv2.data. Accessed on: 17 March 2019.

NAIDOO, R. \& K. HILL, 2006. Emergence of indigenous vegetation classifications through integration of traditional ecological knowledge and remote sensing analyses. Environmental Management 38: 377 387. DOI: https://doi.org/10.1007/s00267-004-0338-9

NAXARA, L., B. T. PINOTTI \& R. PARDINI, 2009. Seasonal microhabitat selection by terrestrial rodents in an old-growth Atlantic Forest. Journal of Mammalogy 90(2): 404-415. DOI: https://doi. org/10.1644/08-MAMM-A-100.1

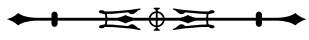


OLSON, D. M., E. DINERSTEIN, E. D. WIKRAMANAYAKE, N. D. BURGESS, G. V. N. POWELL, E. C. UNDERWOOD, J. A. D'AMICO, I. ITOUA, H. E. STRAND, J. C. MORRISON, C. J. LOUCKS, T. F. ALLNUTT, T. H. RICKETTS, Y. KURA, J. F. LAMOREUX, W. W. WETTENGEL, P. HEDAO \& K. R. KASSEM, 2001. Terrestrial ecoregions of the world: A new map of life on Earth. BioScience 51(11): 933-938. DOI: https://doi. org/10.1641/0006-3568(2001)051[0933:TEOTWA]2.0.CO;2

OWEN, R. D., 2013. Ecology of small terrestrial mammals in an isolated Cerrado patch, eastern Paraguay: communities, species, and effects of ENSO, precipitation, and fire. Mastozoología Neotropical 20(1): 97-112.

OWEN, R. D., D. G. GOODIN, D. E. KOCH, Y.-K. CHU \& C. B. JONSSON, 2010. Spatiotemporal variation in Akodon montensis (Cricetidae: Sigmodontinae) and hantaviral seroprevalence in a subtropical forest ecosystem. Journal of Mammalogy 91(2): 467481. DOI: https://doi.org/10.1644/09-MAMM-A-152.1

OWEN, R. D., H. SÁNCHEZ, L. RODRÍGUEZ \& C. B. JONSSON, 2018. Composition and characteristics of a diverse didelphid community (Mammalia: Didelphimorphia) in subtropical South America. Occasional Papers, The Museum of Texas Tech University 358: 1-18.

OWEN, R. D., J. V. CAMP \& C. B. JONSSON, 2019. Sigmodontine community and species responses to El Niño and precipitation in different levels of forest degradation. Therya 10(3): 255-265. DOI: https://doi.org/10.12933/therya-19-899

OWEN, R. D., J. V. CAMP, R. SAGE, L. RODRÍGUEZ, V. J. MARTÍNEZ BRUYN, R. C. MCALLISTER \& C. B. JONSSON, 2020. Sympatry and habitat associations of Sigmodontine rodents in a neotropical forest-savanna interface. Mammalia 84(3): 227 238. DOI: https://doi.org/10.1515/mammalia-2019-0036

OWEN, R. D. \& J. V. CAMP, in press. Bats of Paraguay: specimen data reveal ecoregional preferences and diverse seasonal patterns. Acta Chiropterologica 23(1)

PARDIÑAS, U., G. D'ELÍA, V. FAGUNDES, A. CHRISTOFF \& L. GEISE, 2016. Akodon montensis (errata version published in 2017). The IUCN Red List of Threatened Species 2016: e.T136197A115204938. DOI: https://dx.doi.org/10.2305/IUCN. UK.2016-3.RLTS.T136197A22381864.en

PEEL, M. C., B. L. FINLAYSON \& T. A. MCMAHON, 2007. Updated world map of the Köppen-Geiger climate classification. Hydrology and Earth System Sciences 11: 1633-1644. DOI: https://doi.org/10.5194/hess-11-1633-2007

PEÑA-CHOCARRO, M. C., C. ESPADA-MATEOS, M. VERA, G. CÉSPEDES \& S. KNAPP, 2010. Updated checklist of vascular plants of the Mbaracayú Forest Nature Reserve (Reserva Natural del Bosque Mbaracayú), Paraguay. Phytotaxa 12: 1-224.
PERCEQUiLlO, A., J. PATTON, L. PIRES-COSTA, G. D'ELÍA \& B. PATTERSON, 2016. Hylaeamys megacephalus (errata version published in 2017). The IUCN Red List of Threatened Species 2016: e.T29403A115168269. DOI: https://dx.doi.org/10.2305/IUCN. UK.2016-3.RLTS.T29403A22327685.en

POINDEXTER, C. J., G. D. SCHNELL, C. SÁNCHEZ-HERNÁNDEZ, M. L. ROMERO-ALMARAZ, M. L. KENNEDY, T. L. BEST, M. C. WOOTEN \& R. D. OWEN, 2012. Variation in habitat use of coexisting rodent species in a tropical dry deciduous forest. Mammalian Biology 77(4): 249-257. DOI: https://doi.org/10.1016/J.mambio.2012.03.004

PÜTTKER, T., R. PARDINI, Y. MEYER-LUCHT \& S. SOMMER, 2008. Responses of five small mammal species to micro-scale variations in vegetation structure in secondary Atlantic Forest remnants, Brazil. BMC Ecology 8: 9. DOI: https://doi.org/10.1186/1472-6785-8-9

SÁNCHEZ-MARTíNEZ, J. P. \& R. D. OWEN, 2020. Population characteristics of Akodon montensis (Sigmodontinae) in response to habitat degradation and food availability. Therya 11(3): 1-10.

SANTOS-FILHO, M., D. J. DA SILVA \& T. M. SANAIOTTI, 2008. Edge effects and landscape matrix use by a small mammal community in fragments of semideciduous submontane forest in Mato Grosso, Brazil. Brazilian Journal of Biology 68(4): 702-710. DOI: https://doi. org/10.1590/S1519-69842008000400004

SCHNELL, G. D., M. L. ROMERO-ALMARAZ, S. T. MARTÍNEZCHAPITAL, C. SÁNCHEZ-HERNÁNDEZ, M. L. KENNEDY, T. L. BEST, M. C. WOOTEN \& R. D. OWEN, 2010. Habitat use and demographic characteristics of the west Mexican cotton rat (Sigmodon mascotensis). Mammalia 74(4): 379-393. DOI: https://doi.org/10.1515/ MAMM.2010.052

SIKES, R. S., W. L. GANNON \& THE ANIMAL CARE AND USE COMMITTEE OF THEAMERICAN SOCIETY OF MAMMALOGISTS, 2011. Guidelines of the American Society of Mammalogists for the use of wild mammals in research. Journal of Mammalogy 92(1): 235-253. DOI: https://doi.org/10.1644/10-MAMM-F-355.1

SIKES, R. \& THE ANIMAL CARE AND USE COMMITTEE OF THE AMERICAN SOCIETY OF MAMMALOGISTS, 2016. Guidelines of the American Society of Mammalogists for the use of wild mammals in research and education. Journal of Mammalogy 97(3): 663-688. DOI: https://doi.org/10.1093/jmammal/gyw078

SMITH, P., H. PHEASEY, K. ATKINSON \& J. RAMAKERS, 2012. The Didelphimorphia of Reserva Natural Laguna Blanca, Departamento San Pedro, Paraguay. Acta Zoologica Lilloana 56(1-2): 3-15.

SOLARI, S., E. VIVAR, P. M. VELAZCO, J. J. RODRÍGUEZ, D. E. WILSON, R. J. BAKER \& J. L. MENA, 2001. The small mammal community of the Lower Urubamba Region, Peru. In: A. ALONSO, F. DALLMEIER \& P. CAMPBELL (Ed.): Urubamba: the biodiversity of a Peruvian Rainforest: 171-181. Smithsonian Institution (SI/MAB Series, 7), Washington.

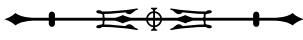


SPONCHIADO, J., G. L. MELO \& N. C. CÁCERES, 2012. Habitat selection by small mammals in Brazilian Pampas biome. Journal of Natural History 46(21-22): 1321-1335. DOI: http://dx.doi.org/10. 1080/00222933.2012.655796

VIEIRA, E. M. \& E. L. A. MONTEIRO-FILHO, 2003. Vertical stratification of small mammals in the Atlantic rain forest of southeastern Brazil. Journal of Tropical Ecology 19(5): 501-507. DOI: https://doi.org/10.1017/S0266467403003559
VOSS, R. \& S. JANSA, 2009. Phylogenetic relationships and classification of didelphid marsupials, an extant radiation of New World metatherian mammals. Bulletin of the American Museum of Natural History (322): 1-177. DOI: https://doi.org/10.1206/322.1 
